\title{
Internal Control Weakness and CEO Media Exposure
}

\author{
Yaying Mary Chou Yeh \\ Framingham State University \\ Hwei C. Wang
University of Maryland Eastern Shore \\ Pei-Ru You \\ Deloitte \& Touche
}

This study selects a sample of Taiwanese electronic firms from 2010 to 2014 to investigate the relationship of firms' internal control weakness (ICW) and CEO media exposure. Empirical evidences show that firms with more internal control weakness experience higher CEO media exposure and the results remain consistent using an alternative measure of media exposure taking into accounting of media tone. This implies that CEOs are concerned with corporate reputation in the media so they will take actions in the media when facing negative events such as internal control weakness.

This study further finds that corporate governance alleviates the above-mentioned relationships. Similarly, family firms would less likely allow CEOs to overly exposed in the media for possible impression management when incurring internal control weakness comparing to non-family firms.

\section{INTRODUCTION}

CEOs may have a complicated love-hate relationship with media coverage (Hamilton \& Zeckhauser, 2004). Nevertheless, CEOs have strong incentive to increase media exposure because the public often views CEOs as image of the firm. Publicity from mass media brings CEO fame and social recognitions and eventually leads to better career outcomes. Prior literature reveals that CEO's media coverage is positively associated with job acquisition and pay premiums (Falato, Li, \& Milbourn, 2015; Malmendier, \& Tate, 2009; Rajgopal, Shevlin, \& Zamora, 2006). Additionally, past literature confirms that CEO's media exposure improves firms' information environments and market pricing (Drake, Guest, \& Twedt, 2014; Tetlock, 2010; Bushee, Core, Guay, \& Hamm, 2010; Fang \& Peress, 2009; Barber \& Odean, 2008; Busse \& Green, 2002).

As such, it is arguable that CEOs may use mass media to strategically disclose favorable corporate information for their personal interest. Managing the press creates media star CEOs (Blankespoor \& DeHaan, 2015). Guinn (2011) depicts that CEO quotes in the media give a firm greater control over the way the firm is portrayed in the media article. Firms may use CEO media exposure as a way to 
communicate negative news events to their shareholders. In other words, CEOs not only have incentives to increase media exposure but also have the ability to use media for impression management.

Internal Controls over Financial Reporting (ICFR) is a process for providing reasonable assurance of financial reporting reliability (PCAOB, Public Company Accounting Oversight Board, 2004). Prior literature shows that disclosing internal control weakness (hereafter ICW) triggers negative consequences in higher risk of stock price crash (Zhou, Kim, \& Yeung, 2013), more expensive cost of equity (Ashbaugh-Skaife Collins, Kinney, \& Lafond, 2009) and adverse market reactions (Du \& Xie, 2011; Hammersley et al., 2008). As such, the reveal of ICW is regarded as bad news. This study expects that CEOs will take actions when news about ICW is conveyed. However, the link between the occurrences of ICW and CEO media exposure is an empirical question which has never been explored.

The purpose of corporate governance is to build an environment of trust, transparency and accountability necessary for fostering long-term investment, financial stability and business integrity, thereby supporting strong growth and more inclusive societies (OECD, 2015). Corporate governance is an important supervision mechanism by the board of directors of a firm. Companies with good corporate governance will monitor behaviors of their management, including CEOs. Well build corporate governance refrains agents from damaging shareholders' interest (Denis, 2001). We extend this study to investigate the role of corporate governance on the ICW-CEO media exposure relationship. The investigation is important because corporate governance contains ways that investor can assure themselves reasonable return on their investment (Shleifer and Vishny, 1997).

Ownership structure of listed firms is an issue of interest to many academics and practitioners around the world. Family ownership is common and family control gives businesses potential advantages of strong leadership and cohesive management teams but has disadvantages of consistent conflict of interest between majority and minority shareholders (Yeh, Lee, \& Woidtke, 2001). Family firms have a higher tendency of appointing family members on the board, management team, and even the CEO position (Prencipe, Markarian, \& Pozza, 2008). Additionally, we test the effects of family firm status on the ICWCEO media exposure relationship. The issue is of importance because of the popularity of family firms in the capital market.

This study selects a sample from Taiwanese electronic firms from 2010-2014 to test the relationship between ICW and CEO media exposure. Using the number of press articles as proxy for CEO media exposure, empirical results indicate a positive association between ICW and CEO media exposure, which imply that the more ICW of a firm, the higher CEO media exposure for impression management. The results remain similar by an alternative measure of CEO media exposure considering media tone.

Further, we find that corporate governance moderate the ICW-CEO media exposure relationship. The results imply that rigorous monitoring of the board limits CEOs' intention for impression management. Family firm status moderates negatively the ICW-CEO media coverage relationship. Family firms constrain their CEOs from overly expose in the media, compared to non-family firms. This study provides empirical evidences on the effects of firms' ICW disclosure on CEOs' impression management behaviors in the media, expanding our understanding on the behavior aspect of ICW.

The study divides into five sections. The introduction section describes motivations and purpose. Section 2 reviews the literature and develops hypotheses. Section 3 describes sample selection process, sources of data, variable definitions and empirical models. Section 4 presents the empirical results. Final section is the conclusions, limitations, and contributions.

\section{LITERATURE REVIEW AND HYPOTHESIS DEVELOPMENT}

\section{Institutional Background - Taiwanese Internal Control System}

At Taiwan, public firms are governed by the Standards for Publicly Held Companies to Internal Control Systems of the Securities and Exchange Act by Securities and Futures Commission (SFC), Ministry of Finance regarding the design and implementation of internal control systems.

The development of Taiwanese internal control system started in 1983 when the Audit Standards Committee of the Accounting Research and Development Foundation published statements on Auditing 
Standards No.1. The Standards of Field Work stipulates that auditors must obtain a sufficient understanding of the entity and its environment, including its internal control, assess the risk of material misstatement of the financial statements, and design the nature, timing, and extent of further audit procedures. Auditing Standard No.5 Investigation and Evaluation of Internal Accounting Control define internal control referring to the four goals of SAP No.29.

The first system formulating internal control on enterprise was issued in 1986. In 1986, the SFC stipulates listed companies should establish the guideline of internal control system and must document such systems and organize an internal audit department. Further, the SFC requires auditors to evaluate internal control of company before issuing an audit report. Thus, listed companies should issue Internal Control over Financial Reporting and Client Letters of Representations after self-assessment. On the other hand, CPAs issue audit report for public firms and letter of internal control recommendations for any concerns in clients' system of internal control.

In 1998, SFC revised the 1992 implementation guidelines. The new implementation guideline requires firms establish a self-assessment on their internal control system and issue Management's Reports on Internal Control. Auditors need to consider the effectiveness of their clients' internal control during their field work for the design of audit procedures.

In 2002, SFC combines the implementation guidelines issued in 1992 into Standards for Publicly Held Companies to Internal Control Systems which is basically in accordance with COSO requirement. However, there is no mandatory requirement on auditors to attest the management's assessment of a firm's internal control system in Taiwan. Material weaknesses of internal controls only need to be disclosed voluntarily.

\section{CEO Media Exposures}

The media is an effective information intermediary that has an advantageous position in collecting, disseminating, and reducing information asymmetry among relevant parties (Fang \& Peress, 2009). One of the primary roles of the media is to highlight relevant information for its readers. Journalists provide benefit to readers by curating and rebroadcasting the most relevant public information, as well as providing independent research and analysis (Severin \& Tankard, 2001; Miller, 2006; Li, Ramesh, \& Shen, 2011). Journalists will consider both readership demand and production costs in their exposure decisions, including whether to expose a CEO in an article. The effects of CEO media exposure are even stronger when the quote of a $\mathrm{CEO}$ has clear, vivid language to personalize a news event (Kennamer, 1988; Clayman, 1995; Jamieson \& Campbell, 2006).

CEOs, on the other hand, are likely to use media exposure to build their reputations for its symbolic image of the firm and its association with executive compensation (Yeh \& Wong, 2017). Several reasons explain the positive relation between CEO media exposure and their career outcomes. First, Stakeholders use CEOs' media coverage as signals of CEOs' ability and effort. Thus, firms benefit from CEO media exposures, and in turn CEOs are compensated for improved firm value. Second, the supply of potential employee in the labor market may increase as CEO visibility increases, allowing a firm to hire highly qualified employees. Finally, media exposure could simply provide the board a plausible justification for providing the CEO's desired level of compensation. Evidences from prior literature support this notion and find that CEO media exposure is positively associated with $\mathrm{CEO}$ career outcomes in job acquisition, job retention, pay premium and stock-based pay-sensitivity (Milbourn, 2003; Hamilton \& Zeckhauser, 2004; Rajgopal et al., 2006; Malmendier \& Tate, 2009; Falato et al., 2015). The boards of directors use media exposure as a low-cost signal of the CEO's performance, so that CEOs with higher media exposure are thought to be more productive, talented, and/or have greater outside employment opportunities, and are compensated accordingly (Rajgopal et al., 2006).

Multiple stakeholders, such as investors, employees, and customers view CEO media exposure as a signal of the CEO's talent or effectiveness, based on the assumption that the media are more likely to expose CEOs that are more talented. Media also influences investors on how they form their opinions on stock values (Tetlock, 2003). To the extent that stakeholders adjust their actions because of CEO visibility, media exposure of the CEO could positively affect firm value. Having a high profile CEO could 
benefit a firm because increased visibility can lead to improved stock value and liquidity (Merton, 1987; Grullon, Kanatas, \& Weston, 2004).

\section{Internal Control Weakness}

Internal control is a mechanism for assuring achievement of an organization's objectives in operational effectiveness and efficiency, reliable financial reporting, and compliance with laws, regulations and policies (COSO, 2013). The updated Internal Control- Integrated Framework Principles proposes five major components ${ }^{1}$ and seventeen principles $^{2}$. Since 2001, Section 404 of SOX requires auditors to report an assessment of a firm's internal controls and attest to management's assessment of the firm's internal control. Material weaknesses of internal controls must be disclosed in auditor and management reports.

Recent literature finds that companies with smaller size, poor profitability, complex transaction type, rapid growth, and arrangement for reorganization are more prone to ICWs (Krishnan, 2005; Doyle, Ge, and McVay, 2007; Naiker and Sharma, 2009). In terms of the impact of ICW on the company, Doyle, Ge, and McVay (2007) suggest that ICW is often associated with poor accrual quality. Chair et al. (2005) suggest that the company disclosed ICW usually have poor financial information quality and is more prone to financial restatement. The greater the number of ICW, the higher the level of earning management (Chan, Farrell and Lee, 2005) . Beneish, Billings and Hodder (2008) find that firms with material weakness have higher information uncertainty and lower financial reporting quality. Firms with internal control deficiencies have significantly higher idiosyncratic risk, systematic risk, and cost of equity (Ashbaugh-Skaife et al., 2009). In other words, investors are exposed to greater information risks on firms with ICW. Zhou et al. (2013) suggest that the presence of ICWs tends to facilitate managers' bad news hoarding, which eventually increases the risk of stock price crash. The disclosure of ICW will have a significant negative market reaction (Du and Xie,2011; Hammersley, Myers, and Shakespeare, 2008).

\section{Internal Control Weakness and CEO Media Exposure}

The role of the mass media is to give pressure on corporate managers and directors to behave in socially acceptable ways (Dyck \& Zingales, 2002). By a sample of Russian firms, Dyck and Zingales (2002) reports that corporate governance violations covered in the Anglo-American press increases the probability of such violations being reversed. Indeed, sustained attention often causes public resentment and pressure (Bushee, Core, \& Guay, 2010). Public opinion on corporate misconduct not only damages the social image of the company and the manager, but also urges other institutions to strengthen board supervision. Prior literature shows that disclosing ICW causes negative consequences in falling stock price (Hammersley et al., 2008), increasing capital cost (Ashbaugh-Skaife et al., 2009), raising audit fees (Keane, Elder, \& Albring, 2012) and poor performance (Esmaeili \& Sharigabadi, 2015).

However, the use and control of information is common in the information age. Impression management literature proposes that firms are engaged in goal-directed activity of controlling or regulating information in order to influence the impressions formed by specific events (Browning et al., 2010). Companies and CEOs have various possibilities to communicate CEO competence to internal and external stakeholder groups. A CEO's strong charisma, reputation, and symbolic power can have a positive effect on corporate reputation (Cravens, Oliver, \& Ramamoorti, 2003), corporate performance (Rajagopalan \& Datta, 1996), organizational effectiveness (Fanelli \& Misangyi, 2006; Waldmann, Ramirez, House, \& Puranam, 2001), and financial analysts' stock recommendations (Gaines-Ross, 2000). Companies and their CEOs therefore have an interest in presenting the persona of the CEO to future employees, the financial community, and the press in order to manage audience impressions and justify the CEO's compensation.

CEO exposures in media articles gives a firm controls over how a firm is portrayed in the media article (Guinn, 2011). When negative event occurs, it is highly likely that CEOs will use media exposure to communicate information about such negative events. Following this line of thought, this study predicts that $\mathrm{CEO}$ will have strong motivations to manage impressions to maintain company and personal reputation. H1 states: 
H1: There is a positive relation between internal control weakness and CEO media exposure.

\section{Sample and Descriptive Statistics}

This study selects a sample of CEOs in the Taiwanese electronic industries, including telecommunication, information technology, consumer electronics and semiconductor business. This industry is the largest sector in Taiwan, representing $80 \%$ or more market value of all listed firms. Electronic businesses are technology oriented, and as such highly cyclical in nature attract much attention from the mass media. Moreover, CEO media exposure proxy requires extensive hand collection of data and individually read through each press articles. Cost and time considerations require us to concentrate on a certain subset of firms in the population. The sample period is from 2010-2014.

We consider general managers as CEOs since listed firms in Taiwan seldom use CEO as a job title. The financial data is from the Fiscal Databanks of the Taiwan Economic Journal (TEJ) and company annual reports. Table 1 reports sample selection results.

TABLE 1

\section{SAMPLE SELECTION}

\begin{tabular}{lc}
\hline & Number of observations \\
\hline Number of electronic industry firms from 2010-2014 & 3737 \\
Delete: Being listed less than three years & $(493)$ \\
Delete: CEO turnover and incomplete data & $(1042)$ \\
Delete: Incomplete data & $(887)$ \\
Delete: Delisting & $(15)$ \\
Delete: Outliers & $(10)$ \\
Number of observations for the main analyses & 1290 \\
\hline
\end{tabular}

\section{VARIABLE DEFINITIONS}

\section{CEO Media Exposure}

Following procedures by previous studies (Milbourn, 2003; Francis, Huang, Rajgopal, \& Zang, 2008), this study conducts content analysis to determine the level of media portrayal for CEOs. The data collection involves searching for a company name in conjunction with the name of the CEO as key words using an internet media database. Knowledge Management Winner covers two most prestigious daily and commercial newspapers published in Taiwan: the China Times and the Commercial Times, as well as several magazines. This study uses article-count as proxy for CEO media exposure (Francis et al., 2008). Further, researchers read through each article to obtain how external parties view the CEO. The focus of this study is to inspect how personality traits affect a firm's decisions, thus personal related reporting is dropped. Articles simply describing a company action, or quoting a CEO are also not included. For robustness test, this study classifies negative and positive media tones. Specifically, we read every press content $^{3}$ and weight one if the tone is positive or neutral and negative one if the tone is negative. 
TABLE 2

ANALYSIS ON THE NUMBER OF ICWS

\begin{tabular}{|l|c|c|c|c|c|}
\hline \multicolumn{1}{|c|}{ Year } & 2010 & 2011 & 2012 & 2013 & 2014 \\
\hline Authority Punishment & 1 & 2 & 0 & 1 & 1 \\
\hline Poor labor relations & 1 & 2 & 6 & 0 & 0 \\
\hline Capital increase rejection and insufficient & 3 & 0 & 4 & 0 & 0 \\
\hline Insider trading & 3 & 0 & 4 & 1 & 0 \\
\hline Litigation case & 20 & 12 & 34 & 61 & 61 \\
\hline Information bulletin & 5 & 3 & 2 & 0 & 0 \\
\hline Environmental protection and safety & 13 & 13 & 9 & 12 & 11 \\
\hline Outside breach of contract & 0 & 0 & 2 & 0 & 0 \\
\hline Going concern opinion & 10 & 10 & 11 & 8 & 8 \\
\hline Hollow out and misappropriate & 0 & 0 & 2 & 1 & 0 \\
\hline Relief-financial distress & 3 & 1 & 10 & 3 & 3 \\
\hline Rumor crisis & 1 & 0 & 0 & 0 & 0 \\
\hline Full delisting & 0 & 0 & 0 & 0 & 1 \\
\hline Substantial loss and net value & 0 & 0 & 0 & 1 & 0 \\
\hline Stock price slump & 1 & 0 & 0 & 0 & 0 \\
\hline Improper internal control & 0 & 2 & 0 & 1 & 1 \\
\hline REL financial distress & 0 & 2 & 0 & 0 & 0 \\
\hline Others & 3 & 12 & 13 & 6 & 14 \\
\hline Total & 64 & 59 & 97 & 95 & 100 \\
\hline
\end{tabular}

\section{Internal Control Weakness}

This study obtains the internal control weakness reporting from Taiwan Corporate Credit Risk Index (TCRI) of Taiwan Economic Journal covering the public information disseminated through newspapers, magazines, and financial report. In this database, the negative events relating financial crisis are mainly divided into financial crisis events ${ }^{4}$, financial crisis precursors ${ }^{5}$ and other negative events ${ }^{6}$. Most of these negative events can be attributed to improper internal control. Chen (2016) suggests that there is a significantly positive relation between internal control weakness and these negative events. According this, we capture the number of negative events as a proxy for internal control weakness.

\section{Regression Model and Control Variable}

We use the model below for this study.

$$
\begin{gathered}
\text { CEO Media Exposure (Media Exposure_1, Media coverage_2) } \\
=\alpha+\beta_{1} I C W+\beta_{2} \text { SIZE }+\beta_{3} \text { Firm age }+\beta_{4} R O A+\beta_{5} \text { Tenure } \\
+\beta_{6} \text { Duality }+\sum_{i=1}^{n} \beta_{i} \text { year }+\varepsilon
\end{gathered}
$$

Following prior studies, this study controls CEO characteristics and firm characteristics affecting CEO media exposure (Blankespoor \& DeHaan 2015). Appendix A specifies each variable in detail. Prior studies find evidence that the media pay more attention to the firm CEOs with better return on assets, larger size, and older firm age (Chih, Lin, Chen, \& Chou, 2009). This study also controls factors that are related with reader demand, such as CEO tenure and duality. Firm year fixed effects is included. 


\section{Descriptive Statistics and Correlation Analysis}

Table 3 reports descriptive statistics. The mean of article count (Media exposure_1) is 1.999. The mean Media exposure_ 2 is 1.912 . The mean of company ICW occurred is 0.333 . For the control variables, the mean (median) firm size is 6.526 (6.444). The mean (median) firm age is 23.837 (23) years. The mean (median) ROA is 0.092(0.089). The mean (median) tenure of CEO is 18.048(16.330) years. On average, 48 percent CEO is chairman of the board at the same time.

Table 4 reports the Pearson correlation coefficients among the variables in the empirical model. Media exposure is positively associated with ICW $(\mathrm{P}=0.000)$. Media exposure_2 is positively associated with ICW $(\mathrm{P}=0.000)$. Further, Media exposure (Media exposure_2) has positive correlations with firm size and ROA.

TABLE 3

DESCRIPTIVE STATISTICS

\begin{tabular}{|c|c|c|c|c|c|}
\hline Variables & Mean & Median & SD & Min & Max \\
\hline $\begin{array}{l}\text { Media } \\
\text { exposure } 1\end{array}$ & 1.999 & 0.000 & 6.574 & 0.000 & 73.000 \\
\hline $\begin{array}{l}\text { Media } \\
\text { exposure_2 }\end{array}$ & 1.912 & 0.000 & 6.290 & -3.000 & 71.000 \\
\hline ICW & 0.333 & 0.000 & 1.019 & 0.000 & 12.000 \\
\hline SIZE & 6.526 & 6.444 & 0.596 & 4.984 & 8.861 \\
\hline Firm age & 23.837 & 23.000 & 8.179 & 6.000 & 53.000 \\
\hline $\mathrm{ROA}$ & 0.092 & 0.089 & 0.084 & -0.383 & 0.368 \\
\hline Tenure & 18.048 & 16.330 & 7.676 & 3.750 & 46.250 \\
\hline Duality & 0.480 & 0.000 & 0.500 & 0.000 & 1.000 \\
\hline $\mathrm{N}$ & 1290 & & & & \\
\hline \multicolumn{6}{|c|}{$\begin{array}{l}\text { Media exposure 1: the number of media count. Media exposure 2: the weighted score of media tone, } 1 \text { if the } \\
\text { article tone is positive or neutral, and -1 if negative. ICW: the numbers of ICW events. SIZE: Natural logarithm } \\
\text { of market value of equity of a company at fiscal year-end. Firm age: number of years since establishment. ROA: } \\
\text { Return on assets, calculated as income before extraordinary items scaled by average assets. Tenure: CEO tenure } \\
\text { in years. Duality: } 1 \text { if CEO is also chairman of the board, and } 0 \text { otherwise. }\end{array}$} \\
\hline
\end{tabular}




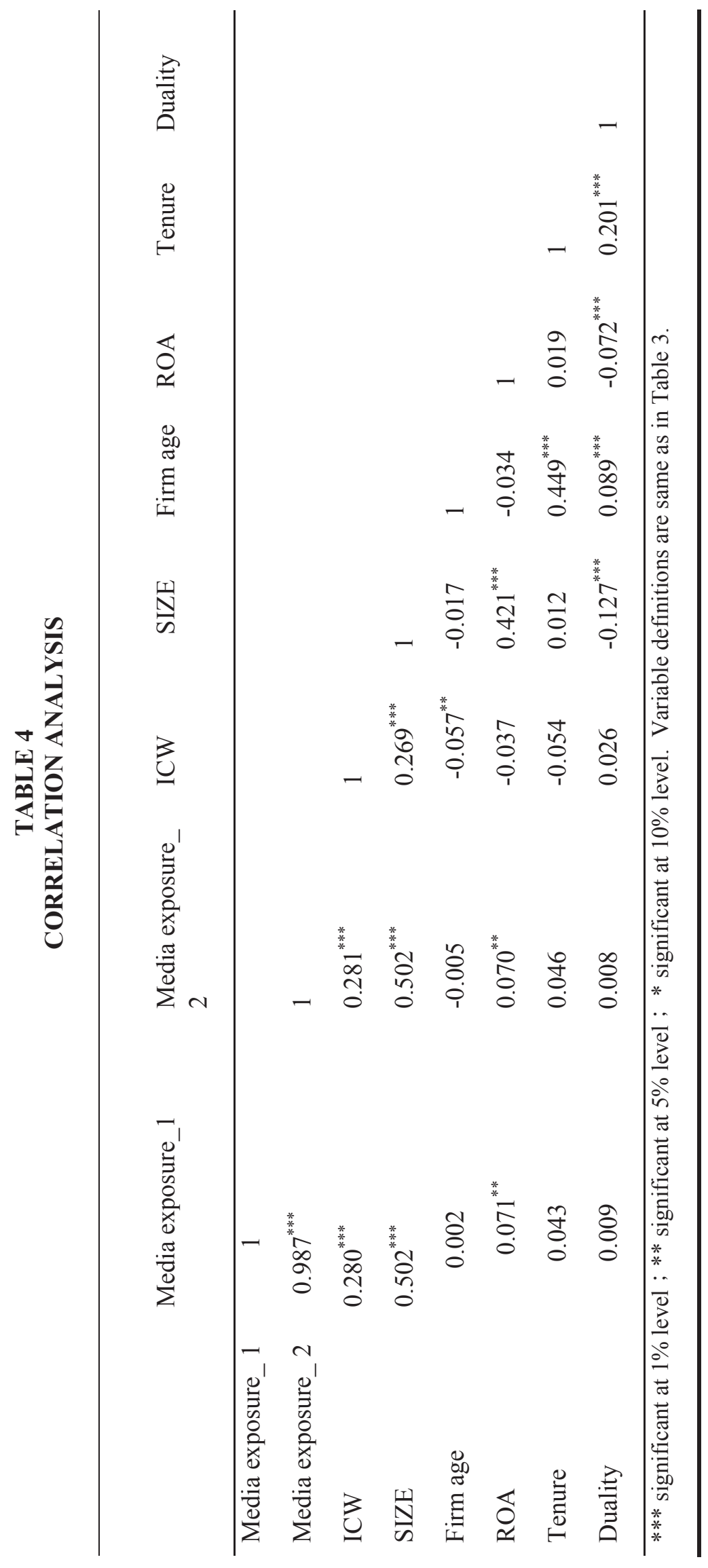

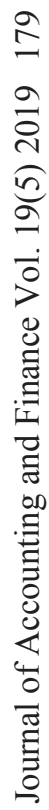




\section{Regression Results}

The purpose of this study is to explore the impact of internal control weakness on CEO media exposure. Table 5 reports regression results. In column 1 of Table 5, ICW is significantly and positively affect CEO media exposure $(0.865, \mathrm{P}=0.000)$, indicating that $\mathrm{ICW}$ indeed leads to higher $\mathrm{CEO}$ media exposure. CEOs tend to do more media management for firms with more internal weaknesses. This result verifies the point that CEOs have an incentive to influence media for possible impression management.

This study further analyzes the content of press articles. Weighted scores are assigned according to the tone of these exposures into positive and neutral (score 1), and negative (-1). Column 2 of Table 5 reports similar results. Internal control weakness (ICW) is still significantly and positively affect CEO media exposure measured by tone $(0.827, \mathrm{P}=0.000)$. CEOs are concerned with their reputation in the media so they will take action when negative events such as ICW happened.

In terms of control variable, empirical results provide evidences that CEO characteristics (Tenure and Duality) play an important role in CEO media exposure. Similarly, ROA and Size of firm characteristics also have significant influences on CEO media exposure. Only firm age is not statistically significant in the regression.

TABLE 5

RESULTS OF REGRESSION ANALYSIS-MAIN TEST

\begin{tabular}{l} 
CEO Media Exposure (Media exposure_1, Media exposure_2) $=\alpha+\beta_{1}$ ICW + \\
\hline$\beta_{2}$ SIZE $+\beta_{3}$ Firm age $+\beta_{4}$ ROA $+\beta_{5}$ Tenure $+\beta_{6}$ Duality $+\sum_{i=1}^{n} \beta_{i}$ year $+\varepsilon$
\end{tabular}

(1)Media exposure_1 (2)Media exposure_2

\begin{tabular}{|c|c|c|c|c|c|c|}
\hline \multicolumn{2}{|l|}{ Variables } & \multirow{2}{*}{$\begin{array}{l}\text { t-value } \\
-18.693\end{array}$} & \multicolumn{2}{|l|}{ p-value } & \multirow{2}{*}{$\begin{array}{l}\text { t-value } \\
-18.762\end{array}$} & \multirow{2}{*}{$\begin{array}{l}\text { p-value } \\
0.000^{* * *}\end{array}$} \\
\hline INTERCEPT & -37.478 & & $0.000 * * *$ & -35.947 & & \\
\hline ICW & 0.865 & 5.404 & $0.000 * * *$ & 0.827 & 5.404 & $0.000 * * *$ \\
\hline SIZE & 5.945 & 19.625 & $0.000 * * *$ & 5.701 & 19.694 & $0.000 * * *$ \\
\hline Firm age & -0.003 & -0.152 & 0.879 & -0.011 & -0.522 & 0.602 \\
\hline ROA & -11.592 & -5.634 & $0.000 * * *$ & -11.283 & -5.739 & $0.000 * * *$ \\
\hline Tenure & 0.039 & 1.695 & $0.090^{*}$ & 0.044 & 1.995 & $0.046 * *$ \\
\hline Duality & 0.729 & 2.293 & $0.022 * *$ & 0.686 & 2.260 & $0.024 * *$ \\
\hline Year-dummy & Included & & & Incl & & \\
\hline $\operatorname{Adj} . R^{2}$ & $29.6 \%$ & & & 29.7 & & \\
\hline $\mathrm{N}$ & 1290 & & & 129 & & \\
\hline \multicolumn{7}{|c|}{$* * *$ significant at $1 \%$ level $; * *$ significant at $5 \%$ level $; *$ significant at $10 \%$ level. } \\
\hline Variable defir & & Tab & & & & \\
\hline
\end{tabular}

\section{Additional Analyses}

The Role of corporate governance on the ICW-CEOs media exposure relationships Agent theory speculates that managers may act in their own self-interest against the goal of maximizing shareholders' wealth (Jensen and Meckling, 1976). Fama (1980) addressees this issue from the perspective of agents' 
reputation incentives. While agents take actions to protect their own reputation, principles can use market forces to supervise agents and make them work harder. Agents are very concerned about their media reputation. Agents are inclined to manage media for self-interest and short-term performance when any events possibly infringe their compensation and career outcomes.

Corporate governance is a supervision mechanism by the board of directors (Cadbury,1992). The board supervises the decision process of the management, moderates decentralization of authority, and inserts motivation measures on the management team in order to protect shareholders' right. We expect that corporate governance may play a role in the ICW-CEOs media exposure relationships. This study uses dummy variable of 1 if firms appoint independent director on the board as proxy for corporate governance quality and observes the interaction term of ICW and IndDirector on CEO media exposure. Table 6 tabulates the results.

The interaction term on ICWxIndDirector are significantly and negatively impact CEO media exposure $(-0.689, \mathrm{P}=0.030)$. The results remain similar using the alternative measure of CEO exposure ($0.606, \mathrm{P}=0.046)$. The results indicate that firms with good corporate governance refrain CEOs in their media exposure when facing ICW, comparing to firms with poorer corporate governance.

\section{TABLE 7}

\section{RESULTS ON ADDITIONAL ANALYSIS - THE MODERATING ROLE OF CORPORATE GOVERNANCE ON THE ICW-CEOS MEDIA EXPOSURE RELATIONSHIPS}

$$
\begin{aligned}
& \text { CEO Media Exposure (Media exposure } \left.{ }_{1} \text {, Media exposure } 2\right)=\alpha+\beta_{1} \text { ICW }+\beta_{2} \text { IndDirector }+ \\
& \beta_{3} \text { ICW } * \text { IndDirector }+\beta_{4} \text { SIZE }+\beta_{5} \text { Firm age }+\beta_{6} \text { ROA }+\beta_{7} \text { Tenur }+\beta_{8} \text { Duality }+\sum_{i=1}^{n} \beta_{i} \text { year }+\varepsilon
\end{aligned}
$$

(1) Media exposure_1

(2) Media exposure_2

\begin{tabular}{lllllll}
\hline Variables & & t-value & p-value & & t-value & p-value \\
\hline INTERCEPT & -37.724 & -18.612 & $0.000^{* * *}$ & -36.233 & -18.703 & $0.000^{* * *}$ \\
ICW & 1.105 & 5.698 & $0.000^{* * *}$ & 1.038 & 5.602 & $0.000^{* * *}$ \\
IndDirector & 0.329 & 0.946 & 0.344 & 0.366 & 1.100 & 0.271 \\
ICW* IndDirector & -0.689 & -2.176 & $0.030^{* *}$ & -0.606 & -2.001 & $0.046^{* *}$ \\
SIZE & 5.960 & 19.683 & $0.000^{* * *}$ & 5.717 & 19.752 & $0.000^{* * *}$ \\
Firm age & -0.001 & -0.069 & 0.945 & -0.008 & -0.407 & 0.684 \\
ROA & -11.613 & -5.647 & $0.000^{* * *}$ & -11.284 & -5.740 & $0.000^{* * *}$ \\
Tenure & 0.037 & 1.606 & 0.109 & 0.042 & 1.926 & $0.054^{*}$ \\
Duality & 0.761 & 2.395 & $0.017 * *$ & 0.714 & 2.351 & $0.019^{* *}$ \\
Year-dummy & Included & & & Included & & \\
Adj.R & & & $29.9 \%$ & & \\
$\mathrm{~N}$ & $29.7 \%$ & & & 1290 & & \\
\hline
\end{tabular}

$* * *$ significant at $1 \%$ level $; * *$ significant at $5 \%$ level $; *$ significant at $10 \%$ level.

Variable definitions are same as in Table 3. 


\section{The Role of Family Firm Status on the ICW- CEOs Media Exposure Relationships}

Family ownership is quite common for listed firms in Taiwan. Family control businesses enjoy the advantage of strong leadership but minority shareholders suffer from possible entrenchment from majority shareholders (Yeh et al., 2001). More than 70\% of the CEOs of Taiwanese family firms are family members (Yang, 2010). Prior studies generate inconsistent results on the effectiveness of internal control for family firms. Mau (1997) indicates that family business establishes looser policies and procedures for top management than non-family business. Lin and Chang (2009) find evidences that family firms are less likely to be involved in fraud than non-family firms are. This study tests the impact of family firm status on the ICW-CEO media coverage relationships.

Table 7 tabulates regression results. The interaction terms on ICW and family firm (ICW*Family Firm) is significantly and negatively impact CEO media exposure $(-0.800, \mathrm{P}=0.010)$ and $\mathrm{CEO}$ media tone $(-0.880, \mathrm{P}=0.003)$. This result indicates that family firm status moderates the ICW-CEO media coverage relationships. When incurring internal control weakness, family firms would not allow CEOs to overly expose in the media for possible impression management, compared to non-family firms.

TABLE 8

RESULTS OF ADDITIONAL ANALYSIS - THE MODERATING ROLE OF FAMILY FIRM STATUS ON THE ICW-CEOS MEDIA EXPOSURE RELATIONSHIPS

\footnotetext{
CEO Media Exposure (Media exposure_1, Media exposure_2) $=$

$\alpha+\beta_{1} I C W+\beta_{2}$ Family Firm $+\beta_{3} I C W *$ Family Firm $+\beta_{4}$ SIZE $+\beta_{5}$ Firm age $+\beta_{6}$ ROA + $\beta_{7}$ Tenur $+\beta_{8}$ Duality $+\sum_{i=1}^{n} \beta_{i}$ year $+\varepsilon$
}
(1) Media exposure_1
(2) Media exposure_2

\begin{tabular}{|c|c|c|c|c|c|c|}
\hline Variables & & t-value & p-value & & t-value & p-value \\
\hline INTERCEPT & -37.305 & -18.556 & $0.000 * * *$ & -35.812 & -18.654 & $0.000 * * *$ \\
\hline ICW & 1.364 & 5.522 & $0.000 * * *$ & 1.372 & 5.815 & $0.000 * * *$ \\
\hline Family firm & -0.052 & -0.150 & 0.881 & 0.033 & 0.100 & 0.920 \\
\hline ICW*Family Firm & -0.800 & -2.579 & $0.010 * * *$ & -0.880 & -2.971 & $0.003 * * *$ \\
\hline SIZE & 5.910 & 19.447 & $0.000 * * *$ & 5.672 & 19.543 & $0.000 * * *$ \\
\hline Firm age & -0.003 & -0.119 & 0.905 & -0.011 & -0.546 & 0.585 \\
\hline $\mathrm{ROA}$ & -11.362 & -5.499 & $0.000 * * *$ & -11.094 & -5.623 & $0.000 * * *$ \\
\hline Tenure & 0.041 & 1.761 & $0.079 *$ & 0.045 & 2.052 & $0.040 * *$ \\
\hline Duality & 0.705 & 2.200 & $0.028 * *$ & 0.673 & 2.199 & $0.028^{* *}$ \\
\hline Year-dummy & Included & \multicolumn{5}{|c|}{ Included } \\
\hline $\operatorname{Adj} . R^{2}$ & $29.9 \%$ & \multicolumn{5}{|c|}{$30.2 \%$} \\
\hline $\mathrm{N}$ & 1290 & \multicolumn{5}{|c|}{1290} \\
\hline \multicolumn{7}{|c|}{$* * *$ significant at $1 \%$ level $; * *$ significant at $5 \%$ level $; *$ significant at $10 \%$ level. } \\
\hline Variable definition & ne as ir & & & & & \\
\hline
\end{tabular}




\section{Robustness Test}

The main objective of internal control is to ensure the reliability of financial reporting, the efficiency and effectiveness of the operation, and to follow the relevant laws and regulations. This study captures the number of negative events relating financial crisis as a proxy for internal control weakness. However, $\mathrm{Wu}$ et al. (2016) consider only seven categories ${ }^{7}$ of negative events being related to ICW. As a robustness test, we use the same categories as proxy for ICW. Table 8 presents the results. The coefficients on internal control weakness remain significant in both columns, consistent with our main results.

TABLE 9

\section{RESULTS OF ROBUSTNESS TEST}

$$
\begin{aligned}
& \text { CEO Media Coverage (Media exposure_1, Media exposure } 22)=\alpha+\beta_{1} I C W-7+ \\
& \beta_{2} \text { SIZE }+\beta_{3} \text { Firm age }+\beta_{4} R O A+\beta_{5} \text { Tenure }+\beta_{6} \text { Duality }+\sum_{i=1}^{n} \beta_{i} \text { year }+\varepsilon
\end{aligned}
$$

\begin{tabular}{|c|c|c|c|c|c|c|}
\hline Variables & & t-value & $p$-value & & $\mathrm{t}$-value & $p$-value \\
\hline INTERCEPT & -38.221 & -18.913 & $0.000 * * *$ & -36.560 & -18.942 & $0.000 * * *$ \\
\hline ICW-7 & 0.825 & 3.783 & $0.000 * * *$ & 0.829 & 3.978 & $0.000 * * *$ \\
\hline SIZE & 6.109 & 20.101 & $0.000 * * *$ & 5.840 & 20.121 & $0.000 * * *$ \\
\hline Firm age & -0.005 & -0.229 & 0.819 & -0.012 & -0.590 & 0.555 \\
\hline ROA & -12.452 & -6.054 & $0.000 * * *$ & -12.059 & -6.138 & $0.000 * * *$ \\
\hline Tenure & 0.030 & 1.308 & 0.191 & 0.035 & 1.603 & 0.109 \\
\hline Duality & 0.862 & 2.703 & $.007 * * *$ & 0.814 & 2.673 & $0.008 * * *$ \\
\hline Year-dummy & Included & & \multicolumn{4}{|c|}{ Included } \\
\hline $\operatorname{Adj} . R^{2}$ & $28.8 \%$ & & \multicolumn{4}{|c|}{$29.0 \%$} \\
\hline $\mathrm{N}$ & 1290 & & \multicolumn{4}{|c|}{1290} \\
\hline
\end{tabular}

$$
\begin{array}{ll}
\text { (1) Media exposure_1 } & \text { (2) Media exposure _ } 2
\end{array}
$$

*** significant at $1 \%$ level $; * *$ significant at $5 \%$ level $; *$ significant at $10 \%$ level.

Variable definitions are same as in Table 3

\section{CONCLUSIONS, LIMITATIONS AND FUTURE STUDIES}

CEOs are concerned with corporate reputation in the media so they will take actions in the media when facing negative events such as internal control weakness. This study selects Taiwanese electronic industries as sample from 2010-2014 to investigate the impact of ICW on CEO media exposure.

Empirical evidences show that firms with higher internal control weakness experience more CEO media exposure, supporting H1. CEOs put extra efforts in appearing in media in respond to the publicity of internal control weaknesses. The results imply that CEOs have incentive to manage media when facing negative events such as the occurrence of internal control weakness. The results remain consistent using an alternative measure of media exposure considering media tone.

This study further finds that corporate governance moderates the ICW- CEO media exposure relationships. Firms with good corporate governance will monitor CEOs in their media exposure when 
facing internal control weaknesses, compared to companies with poor corporate governance so CEO media exposure. Similarly, the results of this study reveal that family firm status is a moderator in the ICW- CEO media exposure relationship. Family firm would not allow CEOs to overly expose in the media for possible impression management when occurring internal control weakness, compared to nonfamily firms.

The Sarbanes-Oxley Act (SOX) mandates management evaluation and independent audits of the effectiveness of firms' internal control system (Ashbaugh-skaife et al., 2009). However, very little is known if such ICW disclosure will affect CEOs' impression management behaviors in the media. The results of this study expand our understanding on the behavior aspect of ICW disclosure and provide management implications for corporate governance.

Potential limitations of this study include sample selection, considering the CEOs need long time to implement major decisions as we delete the CEOs that being in their post for less than three years. Second, classifying the content of press requires subjective judgment. Finally, this study is not able to control all variables affecting CEO media exposure, such as CEO age and analyst expectations due to the incompleteness of the database. Future study can include these variables if data is available.

\section{ENDNOTES}

1. Five major components: Control environment, Risk assessment, Control activities, Information \& communication, Monitoring activities.

2. Seventeen principles: Demonstrates commitment to integrity and ethical values, Exercises oversight responsibility, Establishes structure, authority and responsibility, Demonstrates commitment to competence, Enforces accountability, Specifies suitable objectives, Identifies and analyzes risk, Assesses fraud risk, Identifies and analyzes significant change, Selects and develops control activities, Selects and develops general controls over technology, Deploys through policies and procedures, Uses relevant information, Communicates internally, Communicates externally, Conducts ongoing and/or separate evaluations, Evaluates and communicates deficiencies.

3. Analysis mode: the content of press must involve CEO with the company at the same time. The content of press being favorable for CEO is listed as positive news, such as the company performance is good under the leadership of a CEO and CEO receiving media appraises. The press is classified as negative news, such as criticized the company poor performance due to the leadership of a CEO, closing the factory, CEO made a public apology, or CEO is in dispute. The press is classified as neutral news, if the press doesn't include positive or negative or indicate both.

4. Financial crisis events include bounced cheque, bankrupt, going concern opinion, arrangement and reorganization, relief-financial distress, takeover, full delisting, lock-out due to financial distress, and negative net worth.

5. Financial crisis precursors include hollow out and misappropriate, suspend trading, chairman bounced cheque, contraction of bank money, substantial loss and net value below 5, lock-out is due to recession, and impairment.

6. Other negative events include bailout-non financial distress, authority punishment, poor labor relations, capital increase rejection and insufficient, voidance emerging stock, insider trading, litigation case, information bulletin, environmental protection and safety, outside breach of contract, supervisor bounced cheque, rumor crisis, stock price slump, improper internal control, REL financial distress, others, withdraw announcement.

7. Seven categories of internal control weakness covering business failures, authority punishment, litigation case, illegal event, hollow out and misappropriate, information bulletin, and environmental protection and security. 


\section{REFERENCES}

Ashbaugh-Skaife, H., Collins, D.W., Kinney, W.R., \& Lafond, R. (2009). The Effect of SOX Internal Control Deficiencies on Firm Risk and Cost of Equity. Journal of Accounting Research, 47, 1-43.

Barber, B.M., \& Odean, T. (2008). All That Glitters: The Effect of Attention and News on the Buying Behavior of Individual and Institutional Investors. Review of Financial Studies, 21(2), 785-818.

Beneish, M.D., Billings, M.B., \& Hodder, L.D. (2008). Internal Control Weaknesses and Information Uncertainty. The Accounting Review, 83(3), 665-703.

Blankespoor, E., \& DeHaan, E. (2015). CEO visibility: are media stars born or made? Rock Center for Corporate Governance at Stanford University Working Paper No. 204.

Browning, L. D., Saetre, A.S., Stephens, K., \& Sornes, J.O. (2010). Information and Communication Technologies in Action: Linking Theories and Narratives of Practice. Routledge: NY.

Busse, J.A., \& Green, T.C. (2002). Market Efficiency in Real Time. Journal of Financial Economics, 65, 415-437.

Bushee, B.J., Core, J.E., Guay, W., \& Hamm, S.J. (2010). The Role of the Business Press as an Information Intermediary. Journal of Accounting Research, 48(1), 1-19.

Cadbury, J.J. (1992). Corporate Governance and Disclosure Quality. Accounting and Business Research, 9, 111-124.

Cravens, K., Oliver, E.G., \& Ramamoorti, S. (2003). The reputation index: Measuring and managing corporate reputation. European Management Journal, 21(2), 201-212.

Chair, D.E.H., et al. (2005). Response to the FASB's exposure draft on share-based payment: an amendment of FASB statements No. 123 and No. 95. Accounting Horizons, 19(2), 101-114.

Chan, K.C., Farrell, B.R., \& Lee, P. (2005). Earnings Management and Return-Earnings Association of Firms Reporting Material Internal Control Weaknesses Under Section 404 of the Sarbanes-Oxley Act. Social Science Electronic Publishing.

Chen, H C. (2016). The Relationships between Internal Control Weakness, Corporate Social Responsibility and Financial Distress. The thesis of Accounting department of Fu Jen Catholic University.

Chih, H.H., Lin, Y.E., Chen, W.R., \& Chou, P.H. (2009). Does CEO Media Coverage Affect Firm Performance? Chiao Da Management Review, 29(1), 139-173.

Clayman, S.E. (1995). Defining Moments, Presidential Debates, and the Dynamics of Quotability. Journal of Communications, 118-146.

Denis, D. (2001). Twenty-five years of corporate governance research and counting. Review of Financial Economics, 10(3), 191-212.

Doyle J., Ge, W., \& Mcvay, S. (2007). Accruals Quality and Internal Control over Financial Reporting. The Accounting Review, 82(5), 1141-1170.

Drake, M.S., Guest, N.M., \& Twedt, B.J. (2014). The Media and Mispricing: The Role of the Business Press in the Pricing of Accounting Information. The Accounting Review, 89, 1673-1701.

Du, X., \& Xie, Z. (2011). Market reaction to disclosure of internal control deficiencies in separation of duties. International Conference on Artificial Intelligence, Management Science and Electronic Commerce, 1228-1231.

Dyck, A., \& Zingales, L. (2002). The corporate governance role of the media. CRSP working paper No. 543.

Esmaeili, S., \& Sharifabadi, A. (2015). Internal Control Weakness, Firm Performance, and Cost of Capital of the Companies Listed in Tehran Stock Exchange. International Journal of Management, Accounting \& Economics, 1(1), 71-87.

Falato A., Li, D., \& Milbourn, T. (2015). Which Skills Matter in the Market for CEOs? Evidence from Pay for CEO Credentials. Management Science, 61(12), 2845-2869.

Fanelli, A., \& Misangyi, V.F. (2006). Bringing out charisma: CEO charisma and external stakeholders. Academy of Management Review, 31(4), 1049-1061. 
Fang, L., \& Peress, J. (2009). Media coverage and the cross-section of stock returns. The Journal of Finance, 64(5), 2023-2052.

Francis, J., Huang, A.H., Rajgopal, S., \& Zang, A.Y. (2008). CEO reputation and earnings quality. Contemporary Accounting Research, 25(1), 109-147.

Gaines-Ross, L. (2000). CEO reputation. A key factor in shareholder value. Corporate Reputation Review, 3, 366-370.

Grullon, G., Kanatas, G., \& Weston, J.P. (2004). Advertising, Breadth of Ownership, and Liquidity. The Review of Financial Studies, 17, 439-461.

Guinn, A. (2011). Editor's Corner: Best Practices for Presenting Quotes in Press Releases. Business Wire.

Hamilton, J. T., \& Zeckhauser, R. (2004). Meia coverage of CEOs: Who? What? Where? When? Why? Working Paper, Sanford Institute of Public Policy, Duke University and Kennedy School of Government, Harvard University.

Hammersley, J., Myers, L., \& Shakespeare, C. (2008). Market reactions to the disclosure of internal control weakness and to the characteristics of those weaknesses under Section 302 of the Sarbanes Oxley Act of 2002. Review of Accounting Studies, 13(1), 141-165.

Jamieson, K., \& Campbell, K. (2006). The Interplay of Influence, Sixth edition. Belmont, CA: Wadsworth.

Keane, M.J., Elder, R.J., \& Albring, S. (2012). The Effect of the Type and Number of Internal Control Weaknesses and Their Remediation on Audit Fees. Review of Accounting and Finance, 11(4).

Kennamer, J.D. (1988). News Values and the Vividness of Information. Written Communication, 108123.

Krishnan, J. (2005). Audit committee quality and internal control: an empirical analysis. The Accounting Review, 80(2), 649-675.

Li, E.X., Ramesh, K., \& Shen, M. (2011). The Role of Newswires in Screening and Disseminating Value Relevant Information in Periodic SEC Reports. The Accounting Review, 86, 669-701.

Lin, C. J., \& Chang, C.C. (2009). Abnormal Change of Board Members, Family Firms and Fraud. The International Journal of Accounting Studies, 48, 1-33.

Malmendier, U., \& Tate, G. (2009). Superstar CEOs. The Quarterly Journal of Economics, 124, 15931638.

Mau, N.C. (1997). Internal Control of Family Business. The master thesis of Accounting department of Soochow University.

Merton, R.C. (1987). A Simple Model of Capital Market Equilibrium with Incomplete Information. The Journal of Finance, 42, 483-510.

Milbourn, T.T. (2003). CEO Reputation and Stock-based Compensation. Journal of Financial Economics, 68, 233-262.

Miller, G., S. (2006). The Press as a Watchdog for Accounting Fraud. Journal of Accounting Research, 44(5), 1001-1033.

Naiker, V., \& Sharma, D.S. (2009). Former audit partners on the audit committee and internal control deficiencies. The Accounting Review, 84(2), 559-587.

OECD. (2015). G20/OECD Principles of Corporate Governance. OECD Publishing, Paris. http://dx.doi.org/10.1787/9789264236882-en.

Prencipe, A., Markarian, G., \& Pozza, L. (2008). Earnings management in family firms: Evidence from R\&D cost capitalization in Italy. Family Business Review, 21(1), 71-88.

Rajagopalan, N., \& Datta, D. K. (1996). CEO characteristics: Does industry matter? Academy of Management Journal, 39(1), 197-215.

Rajgopal, S., Shevlin, T., \& Zamora, V. (2006). CEOs' Outside Employment Opportunities and the Lack of Relative Performance Evaluation in Compensation Contracts. Journal of Finance, 61(4), 1813 1844.

Severin, W.J., \& Tankard, J.W. (2001). Communication Theories: Origins, Methods, and Uses in the Mass Media, Fifth edition. New York: Longman.

Shleifer, A., \& Vishny, R.W. (1997). A Survey of Corporate Governance. The Journal of Finance, 52, 737-783.

186 Journal of Accounting and Finance Vol. 19(5) 2019 
Tetlock, P.C. (2003). Giving Content to Investor Sentiment: The Role of Media in the Stock Market. Working Paper, Deparment of Economics, Harvard University.

Tetlock, P. (2010). Does Public Financial News Resolve Asymmetric Information? Review of Financial Studies, 23, 3520-3557.

Waldmann, D. A., Ramirez, G.G., House, R.J., \& Puranam, P. (2001). Does leadership matter? CEO leadership attributes and profitability under conditions of perceived environmental uncertainty. Academy of Management Journal, 44, 134-143.

Wang C.C., Chuang, H.C., Liu, N.T., \& Shih, H.S. (2014). The Organizational Evolutions and Strategies of Family Businesses in Taiwan. Open Journal of Business and Management, 2, 329-338.

Wu, T. H., Hsiao, T.Y., \& Zeng, C.W. (2016). Internal Control Weakness and Firm PerformanceModerating Effect of Corporate Governance. Journal of Accounting and Corporate Governance, 11(1), 1-26.

Yang, M. L. (2010). The impact of controlling families and family CEOs on earnings management. Family Business Review, 23, 266-279.

Yeh, Y.H., Lee, T.S., \& Woidtke, T. (2001). Family Control and Corporate Governance: Evidence from Taiwan. International Review of Finance, 2, 21-48.

Yeh, Y.M.C., \& Wong, W. (2017, August). Do Reputable CEOs Report Conservatively? 2017 American Accounting Association Annual Meeting and 22nd Annual Ethics Research Symposium, San Diego (to be presented).

Zhou, J., Kim, J. B., \& Yeung, I. (2013). Material Weakness in Internal Control and Stock Price Crash Risk: Evidence from SOX Section 404 Disclosure. Social Science Electronic Publishing. 


\section{APPENDIX}

\section{VARIABLE DESCRIPTIONS}

\begin{tabular}{|c|c|}
\hline Variable Name & Definition \\
\hline \multicolumn{2}{|l|}{ Dependent variable } \\
\hline Media exposure_1 & $\begin{array}{l}\text { A CEO media exposure is measured by media count. The number of } \\
\text { media articles }\end{array}$ \\
\hline Media exposure_2 & $\begin{array}{l}\text { Media tone is measured by the weighted score of media articles. } 1 \text { if } \\
\text { the article is positive or neutral, and - } 1 \text { otherwise. }\end{array}$ \\
\hline \multicolumn{2}{|l|}{ Independent variable } \\
\hline ICW & $\begin{array}{l}\text { Internal control weakness is measured by the numbers of internal } \\
\text { control weakness events be exposed. }\end{array}$ \\
\hline IndDirector & 1 if a firm appoints independent directors, and 0 otherwise. \\
\hline Family firm & 1 for family firm, and 0 otherwise. \\
\hline ICW-Others & $\begin{array}{l}\text { The internal control weakness event is classified as other negative } \\
\text { event. }\end{array}$ \\
\hline \multicolumn{2}{|r|}{ S } \\
\hline SIZE & $\begin{array}{l}\text { Natural logarithm of market value of equity of a company at fiscal } \\
\text { year-end. }\end{array}$ \\
\hline Firm age & Number of years since establishment. \\
\hline ROA & $\begin{array}{l}\text { Return on assets, calculated as income before extraordinary items } \\
\text { scaled by average assets. }\end{array}$ \\
\hline Tenure & CEO tenure in years. \\
\hline Duality & 1 if CEO is chairman of the board at the same time, and 0 otherwise. \\
\hline
\end{tabular}

